\title{
Notes on the Eggs and Larvæ of Some Plymouth Prosobranchs.
}

\author{
By \\ Marie V. Lebour, D.Sc., \\ Naturalist at the Plymouth Laboratory.
}

With Plates I-III.

THE following short descriptions of several of the eggs and larvæ of Plymouth prosobranchs, hitherto unknown or imperfectly known, are brought together, although many of them are not fully worked out. It is hoped in the near future to publish a general account of the British species with reference to all known forms, including those which have been specially described from Plymouth.

Some of those described below have not yet been identified, but it is thought that it is worth while noting them for the benefit of future workers, especially some striking forms, important in the plankton on account of their size. This is notably the case with the three larvæ probably belonging to the Turridæ.

\section{Family Trochide.}

Calliostoma zizyphinum (L.).

\section{(Plate I, Figures 1-5.)}

Robert (1902) has described briefly the spawn and young of this species. It has spawned twice in the Plymouth tanks, the second time the young hatching out and living for some weeks, although not growing to any great size. Eggs laid June, 1915, and June, 1934, in a long gelatinous ribbon, several inches long and 3 or $4 \mathrm{~mm}$. broad, attached at intervals to the glass of the aquarium and part of it floating. Inside the ribbon are numerous yellowish eggs irregularly arranged, each $0.25 \mathrm{~mm}$. to $0.28 \mathrm{~mm}$. when newly laid, covered by a thin membrane, and floating in a nutritive layer in the egg covering, the latter surrounded by a thick layer of jelly, which, originally spherical, by pressing against its neighbour becomes more or less polyhedral (Plate I, Figs. 1, 2). A micropyle is present in the egg-covering of the unfertilised egg. Fertilisation is usually regarded as external, but the second specimen, taken from the tank and placed in a bowl whilst depositing its spawn, continued to lay eggs which developed 
into crawling young. In two days the developing larvæ had spiral shells of about $1 \frac{1}{4}$ whorls and a round velum in front of, and dorsal to, the foot (Plate I, Fig. 3). Egg covering at this stage about $0.4 \mathrm{~mm}$. across. The velum is soon lost and the young emerges, shell $0.32 \mathrm{~mm}$. across, the first whorl and a quarter ornamented with sunken polygonal pits, the edge beginning to be longitudinally striated. The velum has disappeared, front tentacles, eyes and two pairs of lateral tentacles well developed (Plate I, Fig. 4). As the shell grows the sculpture of the shell consists of large sunken areas, at first rounded, then elongated and oblong. Although living for about three weeks the young did not grow much more.

The young of a closely related form, probably Cantharidus sp., was found in the crawling stage, shell $0.50 \mathrm{~mm}$. across. This resembled Calliostoma zizyphinum closely, but the older part of the shell was marked with simple striations and there was only one pair of lateral tentacles (Plate I, Fig. 6). Robert (op. cit.) has shown that the species of Cantharidus (as Trochus) lay their eggs in gelatinous masses, much more compact and smaller than those of Zizyphinus (=Calliostoma), and that the young also hatch in the crawling stage.

\section{Family RISSOID止.}

\section{Genus Cingula.}

Sub-genus Parvisetia.

Cinqula fulgida (J. Adams)=Parvisetia fulgida of Plymouth'Fauna 1931.

\section{(Plate I, Figure 7.)}

This species is now found to be very common among seaweeds and corallines on our coasts. Breeding recorded and described here for the first time. Eggs laid singly in small tough spherical capsules attached to corallines by a small portion of the surface. Capsule 0.32 $\mathrm{mm}$. across (Plate I, Fig. 7) ; newly laid egg 0.14 mm. across, enlarging as the animal develops. Hatches in the crawling stage when the small shell is about $0 \cdot 16 \mathrm{~mm}$. across, dark brown. The capsule, egg and young are very similar to those of Barleeia unifasciata, but very much smaller and the young can always be distinguished by its light yellowish brown operculum, that of B. unifasciata being red (see Lebour, 1934 a).

\section{Sub-genus Cingula.}

Cingula cingillus (Montagu).

(Plate I, Figures 8-10.)

Lives in large numbers under stones below the Laboratory, usually just above high-water mark where there is a good deal of moisture and 
occasional submergence, sometimes below. Both the type and the uncoloured variety are equally common, living together. Breeding recorded and described here for the first time. Eggs laid in captivity in glass bowls with stone, in very narrow cracks and crevices in the stones. Capsules of the typical lens-shape of the rissoids, but only contain one to, rarely, four eggs. Capsule 0.64-0.72 mm. across (Plate I, Fig. 8) ; newly laid eggs about $0 \cdot 16 \mathrm{~mm}$., covered with a thin membrane and floating in a nutritious fluid. Young emerge in the crawling stage having passed the veliger stage within the capsule. Newly hatched young $0.48 \mathrm{~mm}$. across with $2 \frac{1}{2}$ whorls (Plate I, Fig. 9-10). Not more than two larvæ were seen in one capsule and usually only one. Shell brownish, except in the colourless variety when it is a dirty white; operculum yellowish. Breeding March. One specimen laid an egg capsule in the dead shell of one of its own species.

\section{Genus Alvania.}

Sub-genus Manzonia.

Alvania crassa (Kanmacher).

(Plate I, Figures 11, 12.)

Egg capsules not yet known. Newly hatched larva and later stages common in the plankton, usually in summer and autumn, rarely in spring, occurs both inside and outside. This larva is described and figured as "unknown rissoid" (Lebour, 1934, a, pp. 529-538, Pl. IV, Figs. 8-10). Youngest larva seen, probably newly hatched, about $0 \cdot 10 \mathrm{~mm}$. across shell which has spiral sculpture with irregular lines in between. After the first whorl and soon after hatching the top of the whorl is unsculptured, the periphery with dots forming irregular spiral striæ. Whorls somewhat more scalariform than most of the older rissoid larvæ (Plate I, Figs. 11, 12), the embryonic shell of about $2 \frac{1}{2}$ whorls being longer and narrower, about $0.48 \mathrm{~mm}$. high when ready to metamorphose. Animal colourless or yellowish. Before metamorphosis there is brown pigment at the base of the the foot which disappears. The embryonic whorls with the characteristic sculpture of the first one show plainly on an adult specimen reared in a plunger jar from a late planktonic larva, but the sculpture is usually rubbed off in adults collected in their natural habitat (apparently they live on sandy bottoms in shallow water) and it is therefore impossible to identify the larvæ by the sculpture of the adult whorls except by rearing.

Lovén (1839) described and figured the first recognisable rissoid larva (a late stage with a large velum and several whorls) which he attributed to the present species (Rissoa costata). This might be, however, from the figure, any typical rissoid which remains as a veliger for some time, and it 
resembles $R$. parva more closely than $A$. crassa now described. Simroth (1911) reproduces Lovén's figure in "Nordisches Plankton" which at that time appeared to be the only late rissoid larva known.

\section{Sub-genus Turboella. \\ Rissoa sarsii Lovén.}

(Plate I, Figure 13.)

It has already been shown (Lebour, 1935) that the planktonic egg capsules attributed to this species in a former paper (Lebour, $1934 \mathrm{a}$, pp. 533-536, Pl. I, Figs. 2-8) do not belong to it but to Littorina neritoides. The true eggs of this species have now been seen, for adults reared in plunger jars from the late larvæ laid egg capsules on weeds (October), the late larvæ having been obtained in April. The capsules, $0.48 \mathrm{~mm}$. across, laid on the sides of glass aquaria and on weeds were of the typical rissoid form (Plate I, Fig. 13). They were quite colourless, with thick walls, and about $0.18 \mathrm{~mm}$. high, containing from 10 to 14 eggs, each egg about $0.09 \mathrm{~mm}$. across. Larvæ in all stages are described in the previous paper where it is shown that the very young larvæ serve as an important food for the larval herrings in winter.

\section{EXPLANATION OF PLATE I.}

Figs. 1-5.-Calliostoma zizyphinum.

1. Portion of egg ribbon.

2. The same more highly magnified.

3. Veliger inside egg covering.

4. Newly hatched young, much magnified, $0 \cdot 32 \mathrm{~mm}$.

5. Shell of slightly older young $0 \cdot 40 \mathrm{~mm}$.

FIG. 6.-Cantharidus sp.? Crawling young soon after hatching $0.5 \mathrm{~mm}$. across.

FIG. 7.-Cingula fulgida. Egg capsule with developing egg $0.32 \mathrm{~mm}$. across.

Figs 8-10.-Cingula cingillus.

8. Egg capsules with newly laid eggs, capsule $0 \cdot 72 \mathrm{~mm}$. across.

9. Egg capsules with developed young nearly ready to hatch.

10. Shell of newly hatched young $0.64 \mathrm{~mm}$. high.

Figs. 11, 12.-Alvania crassa.

11. Late larvæ, shell 0.32 to $0.48 \mathrm{~mm}$. high, showing under surface of foot.

12. Apex of adult shell, showing typical sculpture.

FrG. 13.-Rissoa sarsii. Egg capsules $0.48 \mathrm{~mm}$. across.

Figs. 14, 15, 16. Tornus subcarinatus.

14. Young veligers.

15. Shell of some more highly magnified.

16. Metamorphosed animal $0 \cdot 48 \mathrm{~mm}$. across.

FIG. 17.-Rissoella diaphana. Egg capsules $0.48 \mathrm{~mm}$. long and newly hatched voung, shell $0.24 \mathrm{~mm}$. across. 
PLATE I.
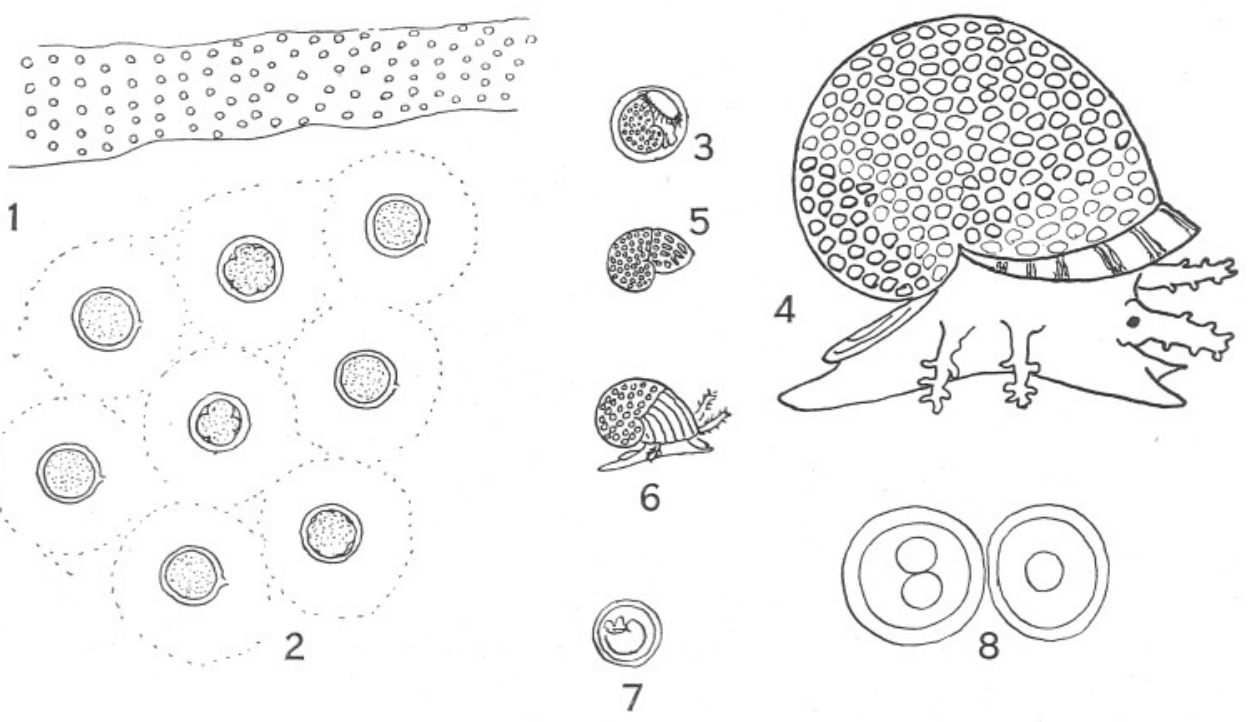

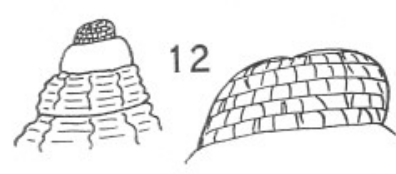
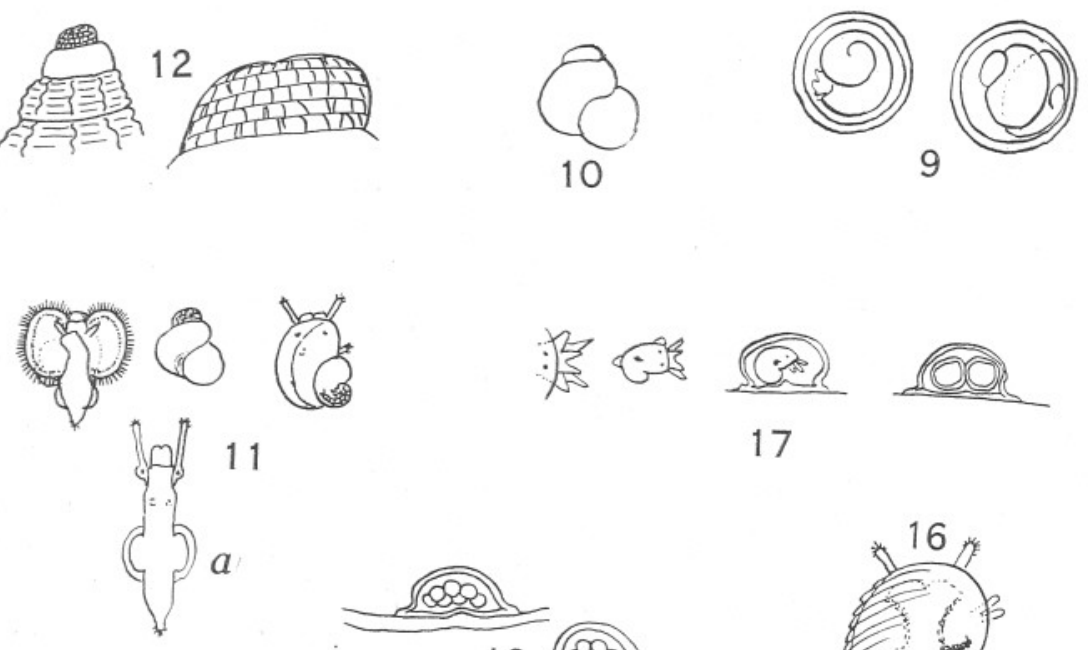

哆
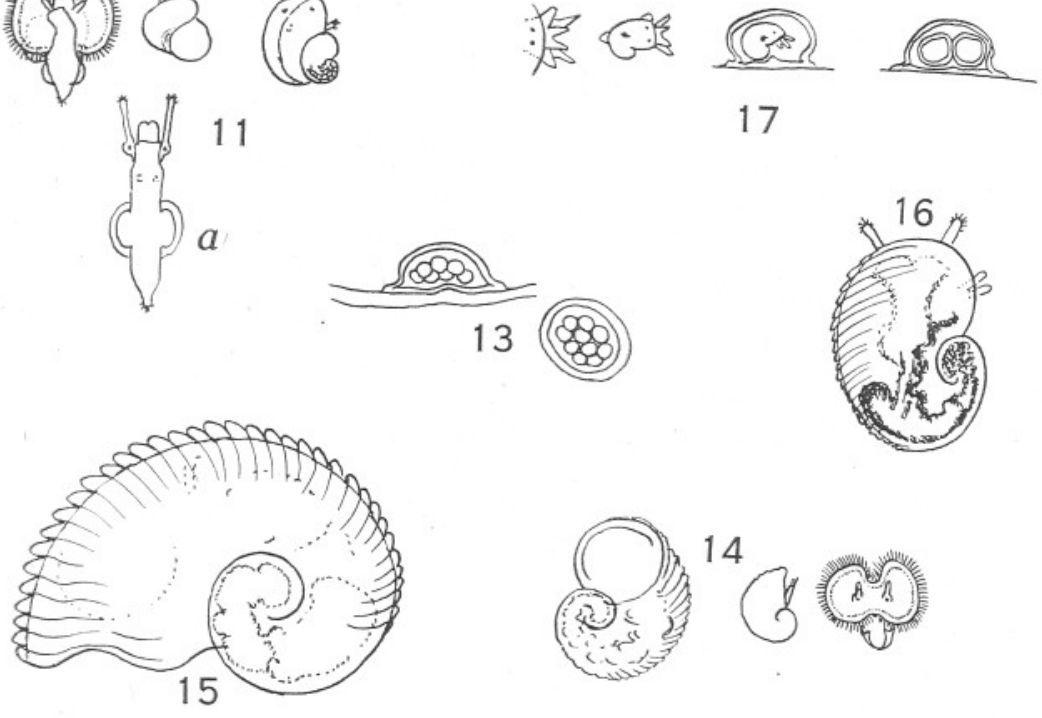


\title{
Family ToRNIDe.
}

\section{Genus Tornus.}

\author{
Tornus subcarinatus (Montagu).
}

(Plate I, Figures 14-16.)

Adults very local on rocks between tide marks. Larvæ common in the inside plankton at Plymouth in summer. Eggs unknown. Larvæ described here for the first time. Smallest veligers seen about $0 \cdot 16 \mathrm{~mm}$. across shell with bilobed velum, shell smooth. At the beginning of about the second whorl there are conspicuous ridges which appear in side view as knobs round the periphery (Figs. 14, 15). Shell very flat with almost circular aperture; velum colourless; animal very dark. Late larva, about $0.48 \mathrm{~mm}$. across shell, metamorphosed in bowl, showing the peculiar and characteristic bilobed pallial tentacle (Fig. 16). No eyes could be seen in the metamorphosed larva.

\section{Family RISSOELLIDe.}

\section{Genus Rissoella.}

\section{Rissoella diaphana (Alder).}

(Plate I, Figure 17.)

Common in the rock pools round about Plymouth among weeds on which it deposits its eggs which were also laid in captivity. Jeffreys (1867, IV, p. 60) states that " the spawn deposited by one individual consisted of only two ova, which are enclosed in a hemispherical case." The Plymouth specimens agree with Jeffreys' description. Capsule hemispherical, thick-walled, $0.48 \mathrm{~mm}$. long and about $0.25 \mathrm{~mm}$. broad, attached by the flat base to green or red algæ, each with one or two eggs about $0.2 \mathrm{~mm}$. across covered with a thin membrane, albuminous layer and egg covering, and floating in a fluid within the capsule. Young emerge in the crawling stage, having passed the veliger stage within the covering. Shell of newly hatched young about $0 \cdot 24 \mathrm{~mm}$. across, light brown, transparent; animal with two pairs of tentacles already developed and a conspicuous black patch dorsally on the left side, resembling in appearance the primitive kidney of the Opisthobranchs. Young in all stages to be found crawling among the weeds in summer.

This species is a new record for Plymouth. 


\section{Family Cжcide.}

Genus С Ссum.

Cocum imperforatum (Kanmacher).

\section{(Plate II, Figures 1-5.)}

Occasionally dredged in the Plymouth neighbourhood, but must be abundant as its larvæ are common in summer and autumn plankton. Owing to its small size the adult is probably overlooked. Mr. D. P. Wilson found two live specimens in dredgings on fine sandy mud from the Eddystone grounds, $1 \cdot 2 \mathrm{~mm}$. long (Figs. 4, 5). The apex of the young shell is spiral and this always breaks off in the adult leaving a flat top filled in by a shelly mass. Veligers in inside and outside plankton, with about $2 \frac{1}{2}$ whorls to the spiral planorbiform shell (Fig. 3), body whorl beginning to uncoil and aperture round, $0.32 \mathrm{~mm}$. across. Animal with yellowish digestive gland and purple near the head. Velum bilobed, with purple at the sides (Fig. 1). Metamorphosed in a bowl, losing the velum and crawling. Operculum very thick.

\section{Family Cerithinde.}

\section{Genus Bittium.}

\section{Bittium reticulatum (Da Costa).}

\section{(Plate II, Figures 6-8.)}

Meyer and Möbius (1872) have described and figured the spawn on a flat slimy spiral coil, ca. $3 \mathrm{~mm}$. across. Lo Bianco (1888, p. 417) describes it as a white ribbon irregularly folded on itself, breeding January, May. Such an egg mass was collected by Mr. F. S. Russell from 2 miles off St. Ives, in July, 1935. It almost certainly belongs to this species, ribbon ca. $24 \mathrm{~mm}$. long, doubled twice on itself, and $0.48 \mathrm{~mm}$. wide, containing round masses $c a \cdot 0 \cdot 32 \mathrm{~mm}$. across of very opaque eggs, causing the whole to appear white. Veligers almost certainly belonging to this species are common in the Plymouth plankton, usually inside, occasionally outside, in spring and summer, the shells corresponding well with the adult apex (Fig. 8). Late larva (Figs. 6, 7) with pale horn-coloured shell, smooth, with $2 \frac{1}{2}$ whorls, loosely coiled, the whorls much rounded; outer lip produced into a large process as in the other known larvæ of the family. Velum colourless. Metamorphoses when shell is about $0.32 \mathrm{~mm}$. high. 


\section{Genus Cerithiopsis. \\ Cerithiopsis tubercularis (Montagu).}

(Plate II, Figures 9-10.)

The larvæ have already been described (Lebour, 1933). The eggs have now been obtained from the parent in captivity. This species lives commonly at Plymouth among sponges, especially Hymeniacedon sanguineum in the Sound. Holes were bitten in the sponge and the eggs laid in little nests, looking very white from the opacity of the eggs.

\section{EXPLANATION OF PLATE II.}

FIGS. 1-5.-Coscum imperforatum.

1-2. Larvæ from plankton, shell $0.32 \mathrm{~mm}$. across.

3. Newly metamorphosed animal.

4-5. Adult, $1 \cdot 2 \mathrm{~mm}$. long.

Figs. 6-8.-Bittium reticulatum.

6. Planktonic veliger, shell $0.32 \mathrm{~mm}$. high.

7. Shell of same.

8. Apex of adult Bittium reticulatum.?

FIGs. 9, 10.-Eggs of Cerithiopsis tubercularis on Hymeniacidon.

9. Capsules laid in sponge.

10. Capsule more highly magnified, $0 \cdot 35 \mathrm{~mm}$. across.

Figs. 11-15.-Chrysallida decussata.

11. Egg capsule, $0 \cdot 35 \mathrm{~mm}$. across.

12. Egg from same, $0 \cdot 12 \mathrm{~mm}$. long.

13. Developing larva.

14. Young shell, crawling, $0 \cdot 48 \mathrm{~mm}$. high.

15. Apex of adult.

Figs. 16-17.-Turbonilla elegantissima.

16. Crawling young $0 \cdot 25 \mathrm{~mm}$. across.

17. Apex of adult.

FIGs. 18-22.-Various planktonic larvæ of the Pyramidelide.

18. (a) $0 \cdot 32 \mathrm{~mm}$. long.

19. (b) $0 \cdot 32 \mathrm{~mm}$. long.

20. (c) $0.35 \mathrm{~mm}$. long.

21. (d) $0.56 \mathrm{~mm}$. across.

22. (e) $0.5 \mathrm{~mm}$. long.

Figs. 23-25.-Calyptraa chinensis.

23. Cluster of egg capsules from under parent shell, $7 \mathrm{~mm}$. acruss.

24. Veliger taken from capsule.

25. Newly hatched young, $0 \cdot 64 \mathrm{~mm}$.

Figs. 26, 27.-Natica catena.?

26. Two views of late larva, shell $0.5 \mathrm{~mm}$.

27. Late larva beginning to metamorphose, shell $0.5 \mathrm{~mm}$.

FIGs. 28, 29.-Natica poliana.?

28. Late veliger, shell $0.8 \mathrm{~mm}$.

29. Metamorphosed young, shell $0.9 \mathrm{~mm}$. 
PLATE II.
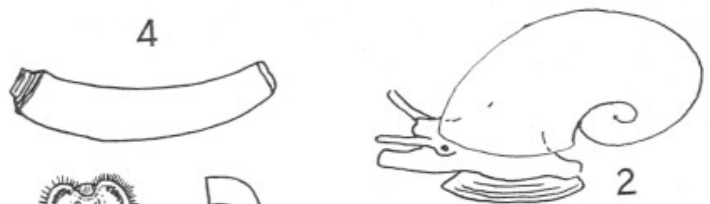

(1) D

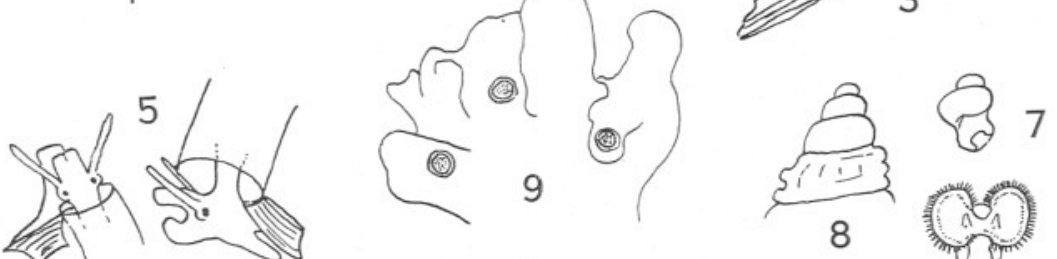
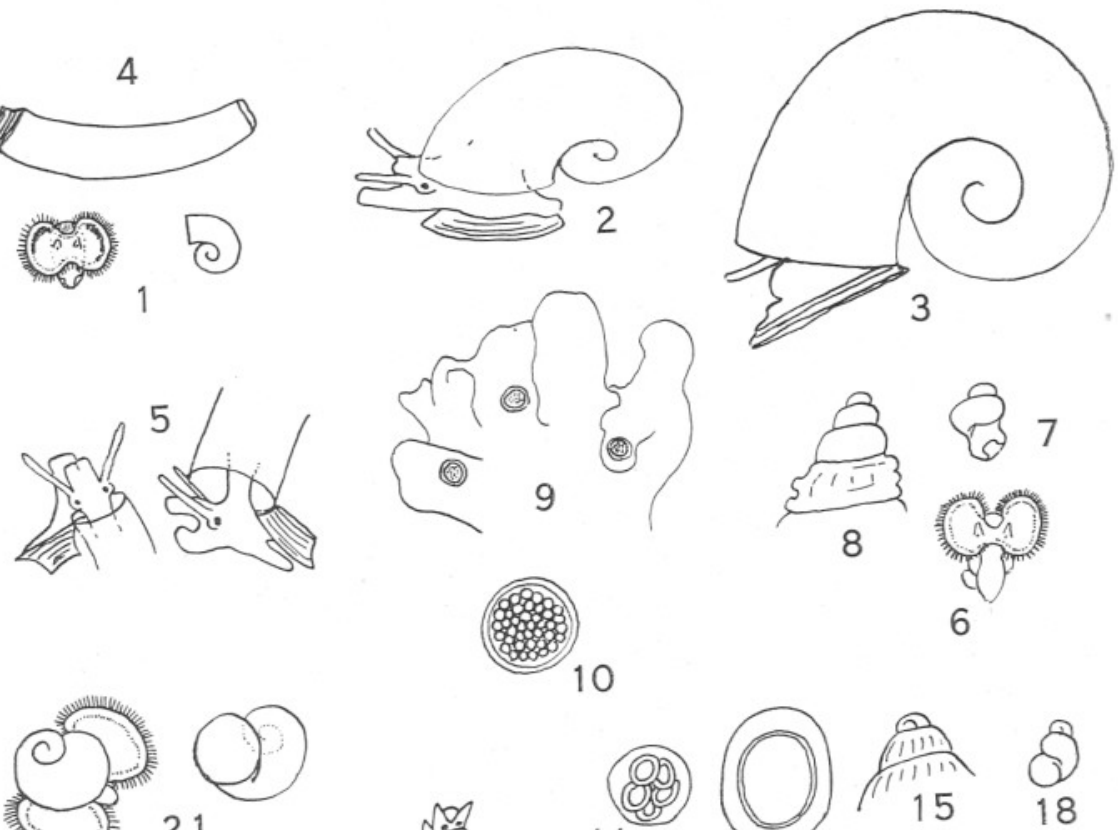

10
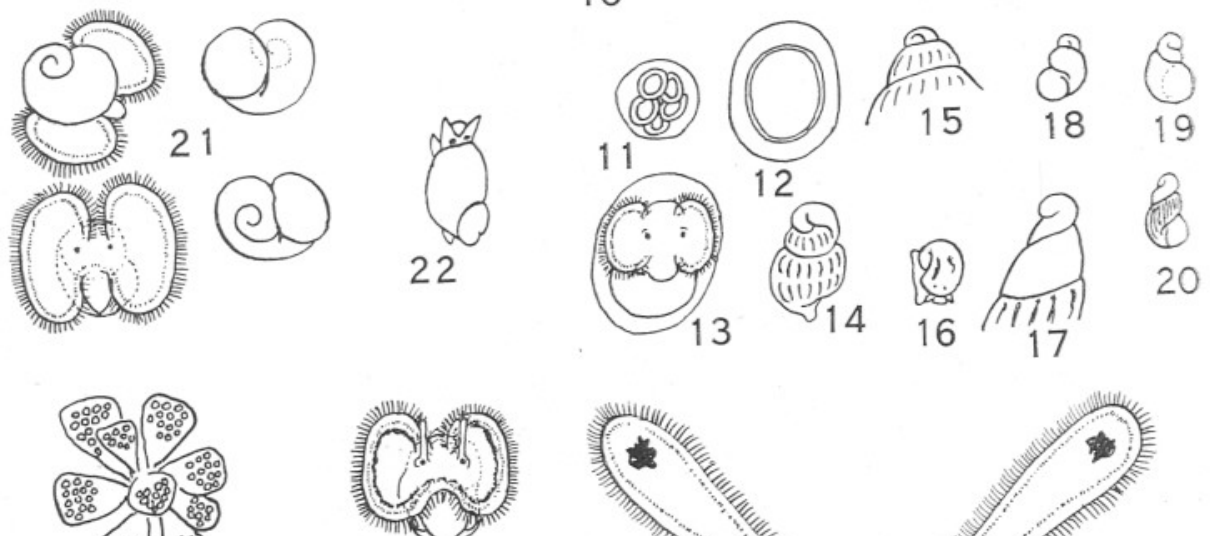

23 \%
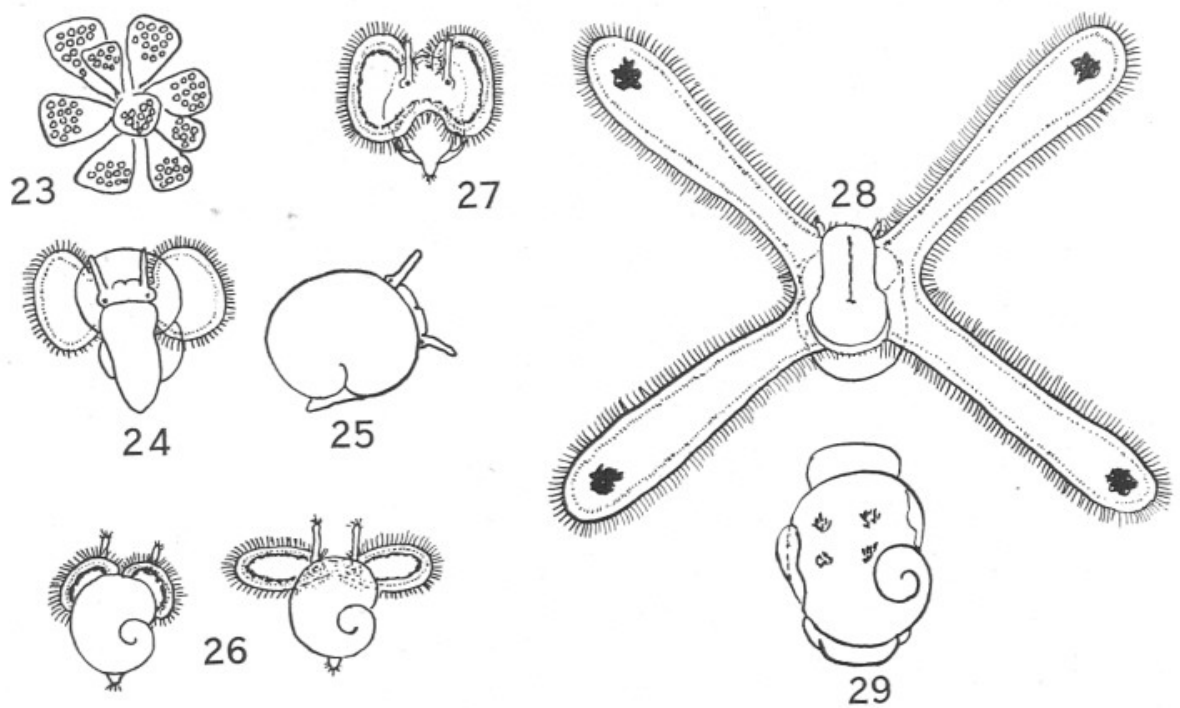
Egg capsule $0.35 \mathrm{~mm}$. across, laid at wide intervals in the sponge. Egg about $0.03 \mathrm{~mm}$. across (Figs. 9 and 10).

\section{Family Pyramidellide.}

As all the members of this family have a reversed apex but a dextral animal the veligers are easy to recognise in the plankton. All whose larvæ are known hatch in the free-swimming stage and many veligers occur in the Plymouth plankton, only few of which can be attributed to the adults. All these have a colourless and transparent shell, smooth at the apex. The eggs which are known are either enclosed in an irregular gelatinous mass (as in Odostomia eulimoides) (see Lebour, 1932) or in small lenticular capsules. The eggs, each covered by a thin membrane and enclosed in an egg covering with a very thick albuminous layer, float together in a fluid enclosed by the capsule. As so little is known of the breeding and larval stages of the members of this family, the few instances given below are worth recording.

\section{Genus Chrysallida.}

Sub-genus Parthenia.

Chrysallida decussata (Montagu) = Pyrgulina decussata of Plymouth Fauna 1931.

(Plate II, Figures 11-15.)

Adult fairly common dredged in the outer grounds. Eggs laid in May on the glass of a plunger jar in very thin-walled lens-shaped capsules, 0.24 to $0.35 \mathrm{~mm}$. across, attached by the lower flat surface to the glass. Four to eight eggs in each capsule (Plate II, Figs. 11, 12), transparent, each egg 0.09 to $0.12 \mathrm{~mm}$. long, oval. Young nearly ready to hatch with sinistral, colourless, and transparent shell of about $1 \frac{1}{2}$ whorls, bilobed velum (Plate II, Fig. 13). Young shells (Plate II, Fig. 14) sometimes found in the plankton with sculpture of lower whorls showing that metamorphosis probably takes place when the shell has about 2 to $2 \frac{1}{2}$ whorls, when it becomes dextral.

\section{Genus Turbonilla.}

Turbonilla elegantissima (Montagu) $=T$. lactea in Plymouth Fauna 1931.

(Plate II, Figures 16, 17.)

The crawling young found with the adult are very small, $0.25 \mathrm{~mm}$. across the shell which is already dextral, therefore the free-swimming 
stage, probably present, must be very short. Eggs unknown. Adults common in the Sound, dredged from muddy ground with stones.

Several different planktonic larvæ with sinistral apices belonging to this family are found at Plymouth. Some of these, not at present identified with any species, are here figured and denoted $a$ to $e$ (Plate II, Figs. 18-22).

(a) Smooth shell, $0.32 \mathrm{~mm}$. long, ca. $3 \frac{1}{2}$ whorls, colourless and transparent, velum bilobed. From inside Sound (Fig. 18).

(b) Very similar to $(a)$ but probably a different species, with a rounder body whorl. Smooth shell, ca. 0.32 mm. long, ca. $3 \frac{1}{2}$ whorls, colourless, transparent, velum bilobed. From outside plankton (Fig. 19).

(c) Shell $0.34 \mathrm{~mm}$. long, ca. $3 \frac{1}{2}$ whorls, third whorl finely striated longitudinally, brown digestive gland, dextral but with sinistral apex, bilobed velum. From station E1, 14 miles beyond Plymouth Breakwater (Fig. 20).

(d) Shell $0.56 \mathrm{~mm}$. across, $2 \frac{1}{2}$ whorls, broad, sinistral, colourless except for a brownish internal lip by the columella. Animal colourless with large colourless bilobed velum. This is the commonest larva of the family at Plymouth, occurring inside the Sound spring, summer and autumn. Metamorphoses with $2 \frac{1}{2}$ whorls when the shell becomes brownish and dextral (Fig. 21).

(e) Crawling young from inside the Sound, shell smooth, $0.5 \mathrm{~mm}$. long, with hardly more than two whorls. Very little sinistral apex showing. Colourless shell and animal. From inside the Sound on mud (Fig. 22).

\section{Family Calyptraeide.}

Calyptroa chinensis (L.).

(Plate II, Figures 23-25.)

The eggs of this species are well known, described by Milne-Edwards (1832), Lo Bianco (1888) and Fischer (1892), the last figuring them. The triangular capsules (Plate II, Fig. 23) are covered by the front part of the parent shell until they hatch in the crawling stage. Capsules fixed in a bunch by their narrow ends to a stone or shell, transparent and colourless, 3 to $3 \frac{1}{2} \mathrm{~mm}$. long, containing about 12 to 25 eggs, each egg about $0.48 \mathrm{~mm}$. across, with thin membrane and all floating in a fluid within the capsule, usually the eggs are concentrated at the broad end. A veliger stage with large bilobed velum is passed within the egg (Fig. 24) and the velum disappears before hatching, the young hatching when the shell is about $0.64 \mathrm{~mm}$. across with $1 \frac{1}{2}$ whorls, whitish, with colourless or yellowish animal. The embryonic shell shows clearly in the adults, which are very common at Plymouth in shallow water among stones and shells. 


\section{Family Naticide.}

Genus Natica.

\section{Sub-genus Lunatia.}

Two larvæ belonging to Natica are important in the Plymouth plankton, representing Natica catena and $N$. poliana, both occurring commonly in spring and summer. Only these two species are recorded from Plymouth, but it is not absolutely certain which larva belongs to which species as they have not been reared until a late enough stage for absolute identification. It is, however, almost certain that the smaller of the two belongs to $N$. catena, being almost wholly confined to the coastal plankton, and the larger to $N$. poliana, which is found commonly both in inshore and outside plankton. They are therefore attributed to these two with a query. N. catena lives on sand in coastal bays, very rarely further out, N. poliana, which is much smaller, has a much wider distribution and is found in coastal waters as well as on the outer grounds. Although the latter is the smaller species, the eggs are larger. Both species, like all the members of the family whose breeding is known, lay their eggs in sandy spirals, the eggs themselves being in capsules glued together in sand, the spawn of $N$. catena being a well-known object and frequently described by the older naturalists. Both the British species from Plymouth have pelagic larvæ which remain as veligers for some time. Odhner (1914) has described the spawn and veliger of either Natica maculata or millipunctata which has a well-developed veliger stage in the plankton, but hatches at such a late stage that on hatching it can both swim and crawl. Thorson (1935) has described the eggs and larvæ of three species, including Natica groenlandica (which is a British species) from East Greenland, all of which hatch in the crawling stage, the veliger stage being passed within the egg.

\section{Natica catena (da Costa).}

(Plate II, Figures 26, 27.)

Although the spawn is well known, the larvæ, except those newly hatched from the egg, have not been described. The spawn coils are commonly dredged from sandy bottoms near Plymouth, usually in spring, about 130-160 mm. across, 40-45 $\mathrm{mm}$. wide. Egg surrounded by a thin albuminous layer and an egg covering $0.16 \mathrm{~mm}$. across, several together in a capsule surrounded by sand grains. Hertling (1932) gives a good photograph of the spawn. Ankel (1930) has described the developing eggs and young in the capsule, some of the eggs devouring the others (nurse eggs). The planktonic larva which I have assigned provisionally to this species has at first a smooth transparent shell of about 
$1 \frac{1}{2}$ whorls and a bilobed velum which is colourless but soon has a thin purple-brown border, the shell enlarging and becoming very much flattened with a wide umbilicus. Later stages have a very globular shell, large bilobed velum with a purple-brown border and yellowish white animal (Fig. 26). These larvæ somewhat resemble those of Nassarius reticulatus (see Lebour, 1932), but as they grow the absence of a large tooth-like process on the outer lip and of the shell siphon in Natica readily distinguishes them. Late larvæ, 0.48-0.5 mm. across, with $2 \frac{1}{2}$ whorls, shell globular, yellowish, foot somewhat pointed. It is now ready to metamorphose and it can both swim and crawl (Fig. 27), then loses the velum and the processes from the foot begin to come up over the shell. These larvæ are almost always found in shallow water, very rarely outside.

Natica poliana Chiagi=Natica alderi of the Plymouth Fauna 1931.

\section{(Plate II, Figures 28, 29.)}

This species is common both inside and outside the Sound on sandy and muddy bottoms. The spawn is frequently seen round Plymouth and was also obtained in captivity. It is in the form of a very much flattened, usually incomplete, slightly spiral ring, about $25 \mathrm{~mm}$. across and $7 \cdot 8 \mathrm{~mm}$. wide. Hertling (op. cit.) has described and figured it as N. pulchella and also the eggs and newly hatched larvæ. Eggs $0 \cdot 24-0 \cdot 32 \mathrm{~mm}$. across the egg covering, egg itself barely $0 \cdot 16 \mathrm{~mm}$. across. Hertling describes the newly hatched larva as having a four-lobed velum which makes the identification of the Plymouth veligers nearly certain. There are no nurse eggs. The later larvæ attributed to this species are larger than those attributed to $N$. catena, especially those nearly ready to metamorphose, about $0.8 \mathrm{~mm}$. across (Fig. 28). At this stage they have about $3 \frac{1}{2}$ whorls, the form and texture of the shell being similar to the shell attributed to $N$. catena. Velum, at first small and only slightly four-lobed, becomes very large, the lobes being drawn out each with a large brown spot at the end; foot rounded behind, front squarish with a groove ventrally in front. At this stage the larva can both swim and crawl, the velar lobes when expanded being much longer than the shell, the larva being very like that of Nassarius incrassatus, but without the large hook-like process on the outer lip and shell siphon. It is thus interesting to find a parallel between the veligers of Nassarius and Natica, each at Plymouth represented by an inshore form (Nassarius reticulatus, Natica catena) and one which also is widely distributed outside (Nassarius incrassatus, Natica poliana), the first pair being small with a smallish bilobed or slightly indented velum, not spreading far outside the Sound, and the second pair having a very large velum with four long lobes, having a wide distribution further out.

After metamorphosis the foot lobes begin to grow up round the shell 
(Fig. 29). This larva of $N$. potiana resembles the figure of a Natica larva given by Simroth (1913) in the Gastropoda in " Nordisches Plankton."

\section{Family MURICIDe.}

\section{Genus Trophon.}

Sub-genus Trophonopsis.

\section{Trophon muricatus (Montagu).}

(Plate III, Figures 1-4.)

Jeffreys (IV, p. 317) describes and figures the egg capsules, but somewhat inadequately. Capsules laid in plunger jar, February to June, lensshaped, $2.5 \mathrm{~mm}$. across, transparent and colourless, attached by the flat surface to the glass, free surface rounded (Figs. 1, 2), each containing from 5 to 8 eggs, $0 \cdot 48 \mathrm{~mm}$. across when newly laid. Surface of capsule with small raised flecks, large thin portion near centre where the young emerge. One individual may lay from 2 to 9 capsules at intervals. Eggs develop slowly into veligers which probably lose the velum before hatching, but this is not certain as the young never hatched although they developed shells and the velum appeared to be diminishing. Shell of veliger inside egg capsule $0.64 \mathrm{~mm}$. across, having a slight sculpture of dot-like spiral lines, with about $1 \frac{1}{2}$ whorls (Figs. 3,4 ). Adult dredged fairly frequently near Plymouth.

\section{EXPLANATION OF PLATE III.}

FIGs. 1-4.-Trophon muricatus.

1-2. Egg capsule, $2.5 \mathrm{~mm}$. across.

3 . Veliger still in egg, dissected out.

4. Shell of same, $0 \cdot 64 \mathrm{~mm}$. across.

Figs. 5-7. Larva provisionally attributed to Mangelia coarctata.

5. Late veliger, shell $1.25 \mathrm{~mm}$. long.

6. Shell of same.

7. The same, metamorphosed shell $1.25 \mathrm{~mm}$. long.

Figs. 8-18.-Larva attributed provisionally to Hoedropleura septangularis.

8. Smallest larva, shell $0 \cdot 48 \mathrm{~mm}$. across.

9-12. Slightly older larvæ.

13-14. Older larvæ shell $0.8 \mathrm{~mm}$. long.

15. Larva beginning to metamorphose, shell $1 \mathrm{~mm}$. high.

16. Metamorphosing larva, shell $1.28 \mathrm{~mm}$. high.

17. Metamorphosed larva, shell $1 \cdot 44 \mathrm{~mm}$. high.

18. Apex of adult shell.

Fics. 19-20. Unknown turrid (ef. Lora).

19. Veliger, shell $1 \mathrm{~mm}$. high.

20. The metamorphosed animal. 
PLATE III.

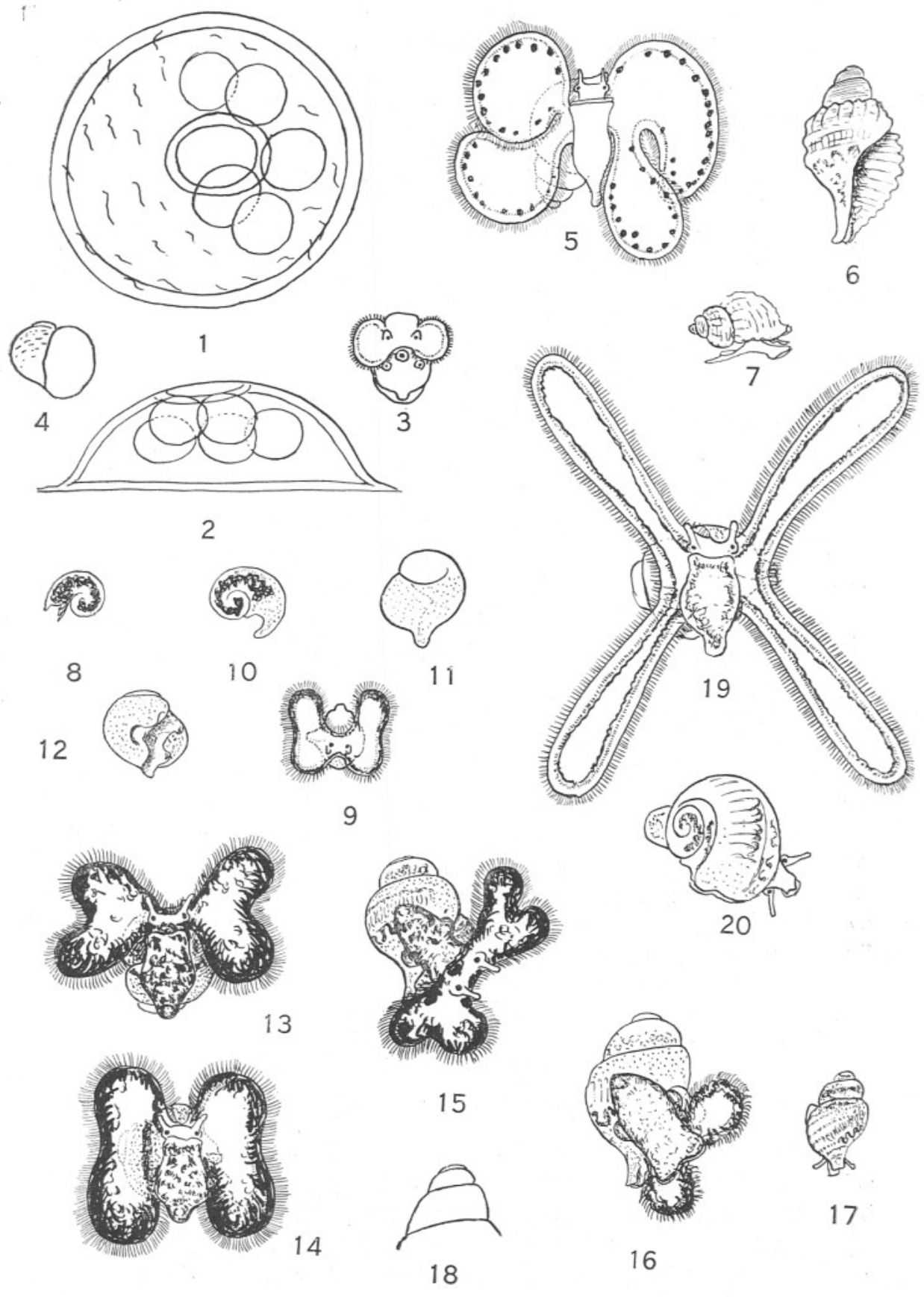




\section{Family TURRIDæ.}

The eggs and young of several of the Turridæ have already been described (Lebour, 1934 b) all of which have very conspicuous planktonic veligers remaining long in the swimming stage and all having lens-shaped egg capsules. Thorson (op. cit. p. 36) has, however, found in East Greenland that several species of Bela (=Lora of Winckworth's list) hatch in the crawling stage and that there are no planktonic larvæ. There are three species almost certainly belonging to this family which occur in the plankton and are peculiarly handsome and conspicuous, but have not yet been identified definitely. One of these is very similar to the larva of Mangelia nebula (see Lebour, 1934 b, Plate I-II), but when it metamorphosed it still retained its operculum. Now the genus Mangelia so far as is known has no operculum, although the closely related genera Hædropleura and Lora possess one. The newly metamorphosed larva of Mangelia nebula, described by myself, loses it directly the velum disappears. It is therefore impossible to be sure that this new larva belongs to Mangelia, especially as Vestergaard (1935) has recently described the newly hatched veligers of Bela turricula (=Lora of Winckworth's list) which are extremely like those of Mangelia nebula. It is therefore possible that this new larva belongs to Lora rufa the adult of which has been recently found at Plymouth, or it may belong to Mangelia coarctata which is fairly common and which is very like $M$. nebula. In the latter case the operculum may be lost later. It is provisionally placed as $M$. coarctata. The other two larvæ which are not identified must also remain for a long time in the plankton for those ready to metamorphose are large with powerful velum. The first of these probably belongs to Hodropleura septangularis, rarely found in the adult stage at Plymouth although these larvæ are fairly common in summer; the second, only one of which has ever been seen, is still absolutely unidentifiable. This is referred to as " Unknown Turrid."

\section{Genus Hædropleura.}

\section{Hadropleura septangularis (Montagu)?}

(Plate III, Figures 8-18.)

Only one adult specimen has been found alive near Plymouth, as far as is known. This was dredged in the Sound. The apex (Fig. 18) is of much the same shape as the larvæ here attributed to this species which are fairly common in the coastal plankton, rarely further out, and which metamorp hosed in captivity into a species of turrid. The youngest larva seen measures about $0.48 \mathrm{~mm}$. across with about $1 \frac{1}{2}$ whorls, smooth shell, process from outer margin of aperture, animal very dark and bilobed 
velum with a very heavy brown border, of the colour of burnt sienna (Fig. 8). Slightly older larvæ have a shell canal, the shell granular on its second whorl, the process on the aperture much larger, the velum large and a still heavier brown border (Figs. 9-12). Later larvæ with shell $0.8 \mathrm{~mm}$. and slightly larger have a heavily granular shell, conspicuous canal, tentacles long, foot slightly lobed behind, very dark animal including heavily pigmented grey foot and the brown of the velum very thick, spreading beyond the margin, the velum being slightly four-lobed (Figs. 13-14). The larva beginning to metamorphose has the shell about $1 \mathrm{~mm}$. high, the velum beginning to dwindle, the foot with opercular lobes (Fig. 15). One with shell $1.28 \mathrm{~mm}$. high had very little velum left (Fig. 16). The newly metamorphosed animal has the shell $1.44 \mathrm{~mm}$. high, the operculum being retained (Fig. 17).

The chief argument against this identification is the very dark colour of the animal in all the larval stages, the adult Hodropleura septangularis being yellowish white. It seems possible, however, that this pigment disappears at any rate in the outer exposed parts of the animal, for in the larval Philbertias there was often grey pigment present which disappeared later.

Unknown turrid (probably belonging to the genus LoRA).

(Plate III, Figures 19, 20.)

Only one specimen has been seen of this form which was a late larva and it metamorphosed in a plunger jar but did not live. From the animal it seems to be certainly a turrid, and from its smooth apex and opercular lobes to the foot it is probably a species of Lora. It is a striking form, shell about $1 \mathrm{~mm}$. long, smooth with a few granular dots, colourless; conspicuous shell siphon, outer lip compressed so that the aperture is narrowed; foot roundish behind with opercular lobes; velum very large with four long lobes, each rather more than twice the length of the shell, bordered with a thin line of brown pigment. Animal greyish, not so dark as the previous species. Tentacles rather long and thin. When metamorphosed the animal siphon projected from the shell siphon. A deep channel runs below the suture from about the second whorl to the anterior corner of the aperture, causing a deep notch. From inside the Sound, July 28th, 1931.

\section{Genus Mangelia.}

Sub-genus Bela.

\section{Mangelia coarctata (Forbes) ?}

(Plate III, Figures 5-7).

This larva is very like $M$. nebula but instead of having a smooth apex it is spirally striated and the animal metamorphoses at a slightly larger 
size. It was only seen once, a late larva, which metamorphosed in a plunger jar. For the reasons given above it is uncertain whether it really is a Mangelia, although this seems highly probable. Shell $1.25 \mathrm{~mm}$. high, first whorl and a half to two spirally striated, the last with longitudinal ribs and spiral lines giving it a somewhat reticulated appearance. Shell siphon fairly long, shell pale yellowish; foot pointed, animal siphon projecting from shell ; tentacles rather long; velum very large, when in action almost covering the shell, four-lobed with large brown and orange spots round the border; animal greyish. When metamorphosed the operculum is still there, but there are no conspicuous opercular lobes on the foot.

\section{LITERATURE.}

Ankel, W. E. 1930. Nahreierbildung bei Natica catena da Costa. Zool. Anz., Bd. 89, pp. 129-135.

Fischer, H. 1892. Recherches sur la Morphologie du Foie des Gastéropodes. Bull. Sci. Franc. et Belgique, XXIV (4), Vol III, pp. 260-346.

Hertling, H. 1932. Zur Kenntnis des Laichbandes und der Veligerlarven von Natica pulchella Risso. Zool. Anz., Bd. 100, pp. 95-100.

Jefrreys, J. G. 1867. British Conchology, Vol. IV, pp. 1-486.

Lebour, M. V. 1931. The Larval Stages of Nassarius reticulatus and Nassarius incrassatus. Jour. Mar. Biol. Assoc., N.S., Vol. XVII, pp. 797-818.

— 1932. The Eggs and Early Larvæ of Two Commensal Gastropods, Stilifer stylifer and Odostomia eulimoides. Ibid., Vol. XIII, pp. 117122 .

1933. The Life Histories of Cerithiopsis tubercularis (Montagu), C. barleei Jeffreys and Triphora perversa (L.). Ibid., Vol. XIII, 2, pp. 491, 498.

— 1934a. Rissoid Larvæ as Food of the Young Herring. The Eggs and larvæ of the Plymouth Rissoidæ. Ibid., Vol. XIX, pp. 523-540. 1934b. The Eggs and Larvæ of some British Turridæ. Ibid., Vol. XIX, pp. 541-544.

— 1935. The Breeding of Littorina neritoides. Ibid., Vol. XX, pp. 373378.

Lo Bianco. 1888. Notizie biologiche riguardanti specialmente il period di maturità sessuale degli animali del golfo di Napoli. Mitt. Zool. Stat. Neapel., Bd. XII, pp. 448-573. 
Meyer, H. A., and MöвIUs, K. 1872. Fauna der Kieler Bucht, Bd. II, pp. 1-139.

Mrlne-Edwards, H., in Audouin and Milne Edwards, 1832. Recherches Histoire Naturelle litt. France. P. 133.

Odhner, N. H. 1914. Notizen über die Faune der Adria bei Rovigno, Beiträge zur Kenntnis der Marinen Mollusken fauna von Rovigno in Istria. Zool. Anz., Bd. 44, pp. 156-171.

Robert, A. 1902. Recherches sur le Développement des Troques. Arch. Zool. Exp. et gén., 3rd Ser., X, pp. 269-558.

Simroth, H. 1911. Die Gastropoden des Nordischen Plankton (Nordisches Plankton). Zool. Teil., Bd. 2, pp. 1-36.

Thorson, G. 1935. Studies on the Egg Capsules and Development of Arctic Marine Prosobranchs. Medd. om Grønland., Bd. 100, Nr. 5, pp. 1-71.

Vestegaard, K. 1935. Leber den Laich und die Larven von Scalaria communis (Lam.), Nassarius pygmaus (Lam.) und Bela turricola (Mont.). Zool. Anz., Bd. 109, Hft. 7-8, pp. 217-222. 